\title{
The Ciliary Neurotrophic Factor/Leukemia Inhibitory Factor/gp130 Receptor Complex Operates in the Maintenance of Mammalian Forebrain Neural Stem Cells
}

\author{
Takuya Shimazaki, Tetsuro Shingo, and Samuel Weiss \\ Genes \& Development Research Group, Department of Cell Biology and Anatomy, University of Calgary Faculty of \\ Medicine, Calgary, Alberta, Canada T2N 4N1
}

The cytokines that signal through the common receptor subunit gp130, including ciliary neurotrophic factor (CNTF), interleukin-6, leukemia inhibitory factor (LIF) and oncostatin $\mathrm{M}$, have pleiotropic functions in CNS development. Given the restricted expression domain of the CNTF receptor $\alpha$ (CNTFR) in the developing forebrain germinal zone and adult forebrain periventricular area, we have examined the putative role of CNTFR/LIFR/gp130-mediated signaling in regulating forebrain neural stem cell fate in vivo and in vitro. Analysis of LIFRdeficient mice revealed that a decreased level of LIFR expression results in a reduction in the number of adult neural stem cells. In adult LIFR heterozygote $(+/-)$ mice, the number of neural stem cells and their progeny in the forebrain subependyma and $\mathrm{TH}$-immunoreactive neurons in the olfactory bulb were significantly reduced. Intraventricular infusion of CNTF into the adult mouse forebrain, in the absence or presence of epidermal growth factor (EGF), enhanced self-renewal of neural stem cells in vivo. Analyses of EGF-responsive neural stem cells proliferating in vitro found that CNTF inhibits lineage restriction of neural stem cells to glial progenitors, which in turn results in enhanced expansion of stem cell number. These results suggest that CNTFR/LIFR/gp130-mediated signaling supports the maintenance of forebrain neural stem cells, likely by suppressing restriction to a glial progenitor cell fate.

Key words: neural stem cells; ciliary neurotrophic factor; leukemia inhibitory factor receptor-deficient mice; gp130; stem cell maintenance; astrocyte differentiation
Neural stem cells that can self-renew and give rise to various types of neurons and glia may play a major role in mammalian CNS development and continue to function throughout adulthood (for review, see Alvarez-Buylla and Temple, 1998; Gage, 2000; van der Kooy and Weiss, 2000). Epidermal growth factor (EGF)-responsive cells in the embryonic and postnatal forebrain germinal zone, later in the adult subependyma, behave as neural stem cells in vivo and in vitro (Reynolds and Weiss, 1992; Morshead et al., 1994) and can be propagated for extended periods in vitro in the presence of EGF (Reynolds and Weiss, 1996). However, neural stem cells in the adult subependyma are relatively quiescent (Morshead et al., 1994). The average cell-cycle time is $\sim 15 \mathrm{~d}$, and the number of neural stem cells does not appear to change throughout adult life, whereas proliferation of their progeny is decreased during aging (Tropepe et al., 1997; Morshead et al., 1998). Despite extensive analysis of factors that regulate proliferation and differentiation of neural stem cells and their progeny (for review, see Cameron et al., 1998; Lillien, 1998a,b), the mechanisms that maintain neural stem cells in an undifferen-

\footnotetext{
Received April 6, 2001; revised July 13, 2001; accepted July 17, 2001.

This work was supported by the Canadian Institutes of Health Research. T.S. was supported by a fellowship from the Neuroscience Network of the Canadian Network of Centers of Excellence. S.W. is an Alberta Heritage Foundation for Medical Research Scientist. We thank Drs. Hideyuki Okano, Keiko Nakao, and Derek van der Kooy, and the Weiss and van der Kooy laboratories, for critical reading of an earlier version of this manuscript. Special thanks to Andrew Chojnacki for suggestions and assistance with the figures. We also thank Joy Goldberg and Dorothea Livingstone for excellent technical assistance.

Correspondence should be addressed to Dr. Weiss at the above address. E-mail: weiss@ucalgary.ca.

T. Shimazaki's present address: Department of Physiology, Keio University School of Medicine, 35 Shinanomachi, Shinjyuku-ku, Tokyo 160-8582, Japan. Copyright (C) 2001 Society for Neuroscience 0270-6474/01/217642-12\$15.00/0
}

tiated state are largely unknown. The principle exception is Notch signaling which, through lateral inhibition, may regulate the commitment of stem cells in CNS development (de la Pompa et al., 1997; Ohtsuka et al., 1999; Wakamatsu et al., 1999; Nakamura et al., 2000; Gaiano et al., 2000) (for review, see ArtavanisTsakonas et al., 1999; Kageyama and Ohtsuka, 1999).

Cytokines related to IL-6, such as cardiotropin-1, ciliary neurotrophic factor (CNTF), leukemia inhibitory factor (LIF), and oncostatin M (OSM), all transmit their signals into a cell through their respective receptor complex containing either homodimers of gp130 or heterodimers comprising gp130 and a partner: LIFR (for cardiotropin-1, CNTF, LIF, and OSM) or the OSM-specific receptor (OSMR) (for review, see Taga and Kishimoto, 1997; Heinrich et al., 1998). Numerous in vitro and in vivo studies have shown that these cytokines have pleiotropic actions on many different cell types (for review, see Heinrich et al., 1998; Turnley and Bartlett, 2000). In vitro studies of the developing CNS have shown that the activation of gp130 by these cytokines promotes differentiation and/or survival of astrocytes (Hughes et al., 1988; Johe et al., 1996; Bonni et al., 1997; Murphy et al., 1997; Gadient et al., 1998; Koblar et al., 1998; Rajan and McKay, 1998; Yanagisawa et al., 1999), oligodendrocytes (Mayer et al., 1994; Gard et al., 1995; Barres et al., 1996; Murphy et al., 1997; Gadient et al., 1998; Marmur et al., 1998), and specific types of neurons (Ip et al., 1991; Oppenheim et al., 1991; Martinou et al., 1992; Richards et al., 1996; Marz et al., 1997; Murphy et al., 1997; Galli et al., 1999). The compelling evidence that these cytokines are essential for maintenance of embryonic stem cells (Smith et al., 1988; Williams et al., 1988; Conover et al., 1993; Rose et al., 1994; Yoshida et al., 1994; Pennica et al., 1995) prompted us to consider whether these cytokines may be candidate molecules for regulating the mainte- 
nance of neural stem cells. Although analysis of null mutants of CNTFR, LIFR, or gp130 has confirmed that these receptors are necessary for differentiation of astrocytes and survival of motor neurons in vivo (DeChiara et al., 1995; Li et al., 1995; Ware et al., 1995; Nakashima et al., 1999), no information regarding their putative roles in the maintenance of neural stem cells has been reported.

To test the hypothesis that gp130-mediated signaling plays a role in the maintenance of neural stem cells, we first used LIFR knock-out mice. We find that LIFR/gp130-mediated signaling is necessary for the maintenance of neural stem cells in vivo. Moreover, we analyzed the actions of CNTF (which activates LIFR/ gp130 complex through CNTFR) on self-renewal and expansion of EGF-responsive neural stem cells in vivo and in vitro. We find that CNTF supports the self-renewal of EGF-responsive neural stem cells by suppressing their lineage restriction to glial progenitor cells.

\section{MATERIALS AND METHODS}

Animals and genotyping. LIFR ${ }^{+/-}$mice generated on the B6,129/J genetic background and C57BL6 STOCK (for expanding the $L I F R^{+/-}$mice) were obtained from The Jackson Laboratory (Bar Harbor, ME). Mice were then bred to allow for the generation of homozygote, heterozygote, and wild-type littermates (Koblar et al., 1998). The genotyping of mice carrying LIFR mutations was performed as described previously (Ware et al., 1995). CD-1 mice stocks were maintained in the University of Calgary Bioscience Animal Resources Center.

Neural stem cell culture and growth factors. Generation and differentiation of spheres from embryonic and adult forebrain were performed as described previously with minor modifications (Reynolds and Weiss, 1992; Reynolds et al., 1992). Briefly, striato-pallidum complexes were removed from mouse embryos at E14 and collected into PBS containing $0.6 \%$ glucose, penicillin $(50 \mathrm{U} / \mathrm{ml})$, and streptomycin $(50 \mathrm{U} / \mathrm{ml}$; both from Life Technologies, Gaithersburg, MD) and then transferred into the standard culture medium composed of DMEM-F-12 (1:1), glucose $(0.6 \%)$, glutamine $(2 \mathrm{~mm})$, sodium bicarbonate $(3 \mathrm{~mm})$, and HEPES buffer $(5 \mathrm{~mm})$, insulin $(25 \mu \mathrm{g} / \mathrm{ml})$, transferrin $(100 \mu \mathrm{g} / \mathrm{ml})$, progesterone $(20 \mathrm{nM})$, putrescine $(60 \mu \mathrm{M})$, and selenium chloride (30 nM) (all from Sigma, St. Louis, MO, except glutamine from Life Technologies). For adult neural stem cell cultures, medial and lateral portions of the lateral ventricle subependyma from the adult brain were dissected from both hemispheres, pooled together, subsequently cut into $1 \mathrm{~mm}^{2}$ fragments, and transferred into the standard culture medium containing $1.33 \mathrm{mg} / \mathrm{ml}$ trypsin, $0.67 \mathrm{mg} / \mathrm{ml}$ hyaluronidase, and $0.2 \mathrm{mg} / \mathrm{ml}$ kynurenic acid (all from Sigma). After $30 \mathrm{~min}$ at $37^{\circ} \mathrm{C}$, the tissue was transferred to the standard culture medium containing $0.7 \mathrm{mg} / \mathrm{ml}$ trypsin inhibitor (Roche Diagnostics, Laval, Quebec, Canada). Tissue pieces were mechanically dissociated with micropipettes. Cells were seeded at various densities into the standard culture medium, which also contained EGF (human recombinant; Peprotech, Rocky Hill, NJ) and/or CNTF (rat recombinant; kindly provided by Dr. Robert Dunn, Montreal General Hospital Research Institute, Peprotech or R \& D, Minneapolis, MN) where indicated. Cells were cultured for $7 \mathrm{~d}$ in vitro (DIV) and formed floating cell clusters (spheres), then subsequently processed for various types of experiments described in the text. All the mice for culture experiments were killed by cervical dislocation.

Implantation of the osmotic pumps and growth factor infusion. Sixteen 8-week-old CD-1 mice (Charles-River, Laval, Quebec, Canada) were anesthetized with sodium pentobarbital $(120 \mathrm{mg} / \mathrm{kg}$, i.p.) and implanted with osmotic pumps (Alzet 1007D; Alza, Palo Alto, CA). The cannulas were located in the right lateral ventricle (anteroposterior $+0.2 \mathrm{~mm}$, lateral $+0.8 \mathrm{~mm}$ to bregma, and dorsoventral $-2.5 \mathrm{~mm}$ below dura with the skull leveled between lambda and bregma). Human recombinant EGF $(33 \mu \mathrm{g} / \mathrm{ml})$ and/or rat recombinant CNTF $(33 \mu \mathrm{g} / \mathrm{ml})$ were dissolved in $0.9 \%$ saline containing $1 \mathrm{mg} / \mathrm{ml}$ mouse serum albumin (Sigma). Each animal was infused for $6 \mathrm{~d}$ with either vehicle alone, EGF, CNTF, or EGF plus CNTF at a flow rate of $0.5 \mu \mathrm{l} / \mathrm{hr}$, resulting in a delivery of $400 \mathrm{ng} / \mathrm{d}$ of each growth factor.

Bromodeoxyuridine labeling and detection. To identify the constitutively proliferating population in the adult mouse subependyma of the lateral ventricles, mice were injected with bromodeoxyuridine (BrdU) (Sigma)
(120 mg/kg, i.p.; dissolved in $0.007 \% \mathrm{NaOH}$ in phosphate buffer) every $2 \mathrm{hr}$ for $10 \mathrm{hr}$ and killed $0.5 \mathrm{hr}$ after the last injection. Brains were processed for immunohistochemistry as described below. Rat monoclonal anti-BrdU (1:50; Sera-Lab, Sussex, UK) (primary antibody) and biotinylated-donkey anti-rat (1:200; Jackson ImmunoResearch, West Grove, PA) (secondary antibody) with streptavidin-Cy3 (1:2000; Jackson ImmunoResearch) were used for BrdU detection. To assess cell proliferation within spheres, $1 \mu \mathrm{M}$ of $\mathrm{BrdU}$ was administrated to the cultures at 3 DIV. After $24 \mathrm{hr}$ of incubation, spheres were mechanically dissociated and plated onto poly-L-ornithine-coated coverslips for $2 \mathrm{hr}$, then processed for immunocytochemistry using Amersham Cell Proliferation Assay kit (Amersham-Pharmacia, Oakville, Ontario, Canada) according to the manufacturer's instructions.

Antibodies and immunohistochemistry. The primary antibodies (final dilution and source) used in this study were as follows: rabbit polyclonal anti-bovine GFAP serum (1:400; Biomedical Technologies Inc., Stoughton, MA); rabbit polyclonal anti-human GFAP IgG (1:50; Sigma); mouse monoclonal anti-O4 IgM (1:20; Roche Diagnostics); mouse monoclonal anti-bovine $\mathrm{S} 100 \beta \mathrm{IgG}$ (1:100; Sigma); rabbit polyclonal anti-tyrosine hydroxylase (1:100; Pel-Freez Biologicals, Rogers, AR); and mouse monoclonal anti- $\beta$-III tubulin IgG (1:100 or 1000 ; Sigma).

Adult mice were anesthetized and perfused transcardially with $4 \%$ paraformaldehyde and $0.16 \mathrm{~m}$ phosphate buffer, $\mathrm{pH}$ 6.9. Brains were post-fixed in the perfusing solution overnight at $4^{\circ} \mathrm{C}$. Brains were cryoprotected for at least $24 \mathrm{hr}$ in $15 \%$ sucrose in $0.1 \mathrm{M}$ PBS, pH 7.2. Serial $14 \mu \mathrm{m}$ coronal cryosections $\left(-20^{\circ} \mathrm{C}\right)$ of mouse forebrain were mounted directly onto gelatin-coated slides, then processed for immunohistochemistry. Sections were post-fixed with $100 \%$ acetone for $30 \mathrm{sec}$ at room temperature, then washed three times (10 min each) with PBS. For the detection of BrdU labeling, sections were initially treated with $1 \mathrm{M} \mathrm{HCl}$ for $30 \mathrm{~min}$ at $65^{\circ} \mathrm{C}$ to denature cellular DNA before the immunohistochemistry. Sections were then incubated for $24 \mathrm{hr}\left(4^{\circ} \mathrm{C}\right)$ in primary antibody diluted in washing solution containing $0.3 \%$ Triton X-100. After incubation in the primary antibody, sections were washed (as above) and incubated with the regular secondary antibodies conjugated to fluorescein or rhodamine for $2 \mathrm{hr}$ or with the biotinylated secondary antibodies $1 \mathrm{hr}$ at room temperature followed by incubation with streptavidin-Cy3 (1:2000; Jackson ImmunoResearch) or streptavidin-horseradish peroxidase (HRP) (1:5000; Chemicon Temecula, CA) for $1 \mathrm{hr}$ at room temperature, in the presence of Hoechst 33258 nuclear stain $(0.015 \mathrm{mg} / \mathrm{ml}$ stock solution diluted to $0.001 \mathrm{mg} / \mathrm{ml}$; Roche Diagnostics). Sections were washed three times (5 min each), and where appropriate incubated in DAB containing HRP substrate solution (Vector Laboratories, Burlingame, CA) for $5 \mathrm{~min}$ followed by a rinse with water, then coverslipped with FluorSave (Calbiochem, La Jolla, CA) or Permount (Fisher Scientific, Pittsburgh, PA) and examined under a Zeiss axiophot microscope. Immunostaining for neurons, astrocytes, and oligodendrocytes in differentiated, sphere-derived cells (on coverslips) was performed as first described by Reynolds and Weiss (1996).

\section{RESULTS}

\section{Reduced numbers and function of neural stem cells in the adult LIF $^{+/-}$forebrain}

Neural stem cells can proliferate in vitro in the presence of EGF and/or FGF-2 to form floating cell clusters termed spheres. These neural stem cells can be maintained for extended periods of time through multiple passages (Reynolds and Weiss, 1996). Clonal analysis has demonstrated that these spheres can be passaged individually, and the resultant secondary spheres generate neurons, astrocytes, and oligodendrocytes. Thus, one can conclude that the majority (if not all) of the sphere-forming cells express the features of neural stem cells. We used this culture system to examine the function of LIFR/gp130 signaling on the maintenance of neural stem cells. Initially, we asked whether selfrenewal or expansion of neural stem cells derived from developing LIFR $^{-1-}$ mice, assessed by sphere formation assay in vitro, would differ from those from wild-type littermates $(w t)$. The number of primary, EGF-responsive sphere-forming cells was not

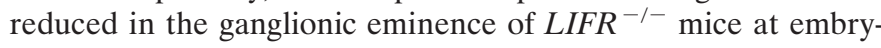
onic day 14 (E14) $(\sim 1 \%$ of the cells plated in both $w t$ and LIFR $^{-/-}$; data not shown). However, when LIFR $^{-/-}$neural stem 
A

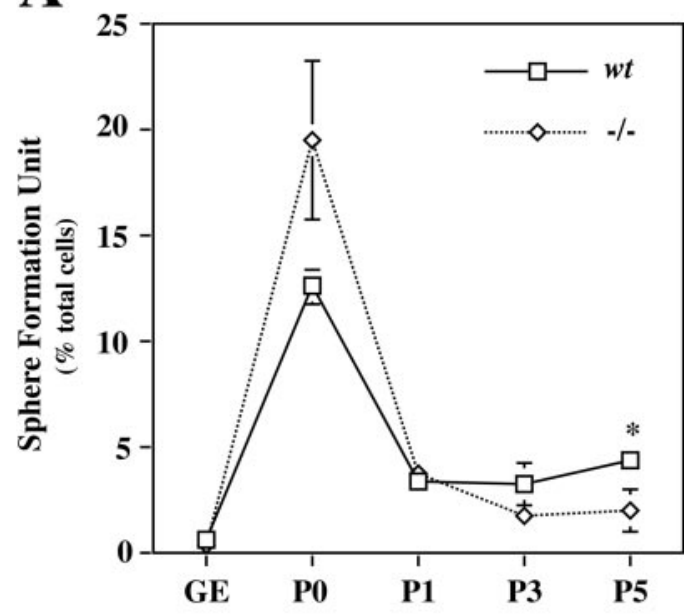

B

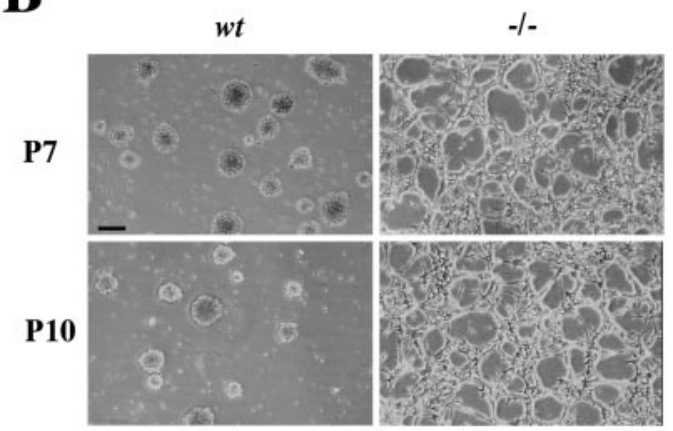

Figure 1. Limited self-renewal and expansion of EGF-responsive stem cells derived from embryonic $L I F R^{-1-}$ mice. Dissociated cells from E14 ganglionic eminences $(G E)$ of wild-type $(w t)$ and $L I F R^{-1-}(-/-)$ mice were plated at an initial density of $2 \times 10^{5}$ cells $/ \mathrm{ml}$ and cultured in EGF-containing growth medium. Resultant spheres were passaged at a density of $5 \times 10^{4}$ cells $/ \mathrm{ml}$ every $7 \mathrm{~d}$. At each passage a portion of the spheres ( $w t$ vs $-/-$ ) was assayed for self-renewal and expansion by counting the number of secondary spheres per total cells formed in low-density cultures (plated at $1 \times 10^{3}$ cells $/ \mathrm{ml}$ ). $A$, Frequency of sphereforming cells in each passage of the cultures. ${ }^{*} p<0.05$ versus $-/-$ cultures; two-tailed $t$ test $(n=4)$. $B$, Morphological changes of the cells and spheres derived from $w t$ and $\operatorname{LIFR}^{-/-}(-/-)$mice after seven and 10 passages. P7, Passage 7; P10, passage 10.

cells were maintained in EGF-containing media in populations of spheres for multiple passages, the number of sphere-forming cells cultures decreased to $\sim 2 \%$ of total cells plated after five passages (Fig. 1A), whereupon it declined precipitously, and sphereforming was entirely lost after seven passages. However, the decrease (between first and second passage) in the sphere formation by $w t$ neural stem cells reached a plateau (Fig. $1 A)(4-5 \%$ of total cells plated) at the second passage and remained at this level for as many as 10 passages (extent of our analysis). Moreover, during the passage of the $L I F R^{-/-}$cells at high density, by the sixth passage the spheres developed into cells possessing a flattened morphology, which gradually attached to the culture flask. Finally, after seven passages, the $L I F R^{-1-}$ cells appeared as proliferating fibroblastic-like cells forming monolayers (Fig. 1B). When these fibroblastic-like cells were plated in differentiation conditions after 10 passages, most of them quickly died (within 3 d) without any sign of differentiation, whereas $w t$ cells from passage 10 spheres were able to differentiate into neurons and glia (data not shown) (Reynolds and Weiss, 1996). These results suggest that LIFR is required for long-term maintenance of sphere-forming neural stem cells in vitro.

Given the results above and that EGF-responsive neural stem cells emerge late in development (E12-E14) (Tropepe et al., 1999), we hypothesized that function of LIFR/gp130 signaling on the maintenance of neural stem cells in vivo may only be apparent in the postnatal to the adult period. However, because homozygous mutants die immediately at birth (as described previously by Ware et al., 1995), we could only analyze heterozygotes for postnatal forebrain neural stem cell numbers and function. Initially we examined the number of EGF-responsive sphereforming cells derived from the postnatal day 0 (P0) lateral ventricles of $L_{I F R}{ }^{+/-}$and $w t$ mice. We did not observe any difference between the number of spheres derived from $w t$ and $L I F R^{+/-}$ mice (data not shown). Therefore, we decided to perform further sphere-formation assays and immunohistochemical analysis in adult forebrains from $L I F R$-deficient mice. In adult $L I F R^{+/-}$ mice (7-12 months old) we found a significant reduction in the constitutively proliferating population of cells, which are the in vivo progeny of EGF-responsive forebrain neural stem cells (Morshead et al., 1994), in the subependyma of the lateral ventricles (Fig. 2). Bromodeoxyuridine immunohistochemistry showed a $55 \%$ reduction in the number of cells in the constitutively proliferating population in the subependyma of heterozygotes (Fig. $2 A, D, G$ ). In addition, the volume of the periventricular area was significantly reduced (Fig. 2B,C,E,F, Table 1), whereas there was no significant change in the pattern of $\mathrm{S} 100 \beta$ expression in the ependyma or GFAP expression in the subependyma. We then asked whether the numbers of EGFresponsive neural stem cells would be reduced in heterozygote forebrains. We found that the number of EGF-responsive sphereforming cells in the periventricular area of the lateral ventricle was reduced by $37 \%$ (Fig. $2 H$ ) in 4- to 8-month-old $L^{2} F R^{+/-}$ mice, compared with $w t$. We did not observe any change in the expansion and multipotency of spheres derived from $L_{I F R^{+/-}}$ mice (data not shown). These results clearly support the involvement of the LIFR in the maintenance of EGF-responsive neural stem cells and in turn the generation of the constitutively proliferating population in the adult forebrain.

A subpopulation of neuronal precursors produced by neural stem cells in the lateral ventricles migrates toward the olfactory bulb through the rostral migratory stream (Lois and AlvarezBuylla, 1994). The ultimate fates of these precursors are as olfactory interneurons localized to the granule and periglomerular layers. Thus, one would hypothesize that the reduction of neural stem cells and their progeny in the periventricular area of the lateral ventricle would result in a reduction in the number of these interneurons. This assumes that the general integrity of the rostral migratory stream is not disrupted, and this is what we observed when comparing sagittal sections of $L_{I F R^{+/-}}$and $w t$ adult mice (data not shown). To ascertain the effect of the reduction of neural stem cells (because of reduced expression of LIFR) on adult neurogenesis in the subependyma of the lateral ventricle, we compared the number of TH-immunoreactive interneurons in the periglomerular layers of olfactory bulbs between LIFR $^{+/-}$and $w t$ adult mice (7-12 months old). As shown in Figure 3, the number of TH-immunoreactive cells was significantly reduced (33\%) in $L I F R^{+/-}$mice. Specifically, it appears as though the number of migrating $\mathrm{TH}$-immunoreactive neurons in the external plexiform layer is reduced (Fig. 3A,B) along with a reduced density of total cells $\left(w t:+/-=1073 \pm 9,925 \pm 18^{*}\right.$ cells $\left./ \mathrm{mm}^{2} ;{ }^{*} p=0.0016 ; n=3\right)$. Total cell number was ascertained 

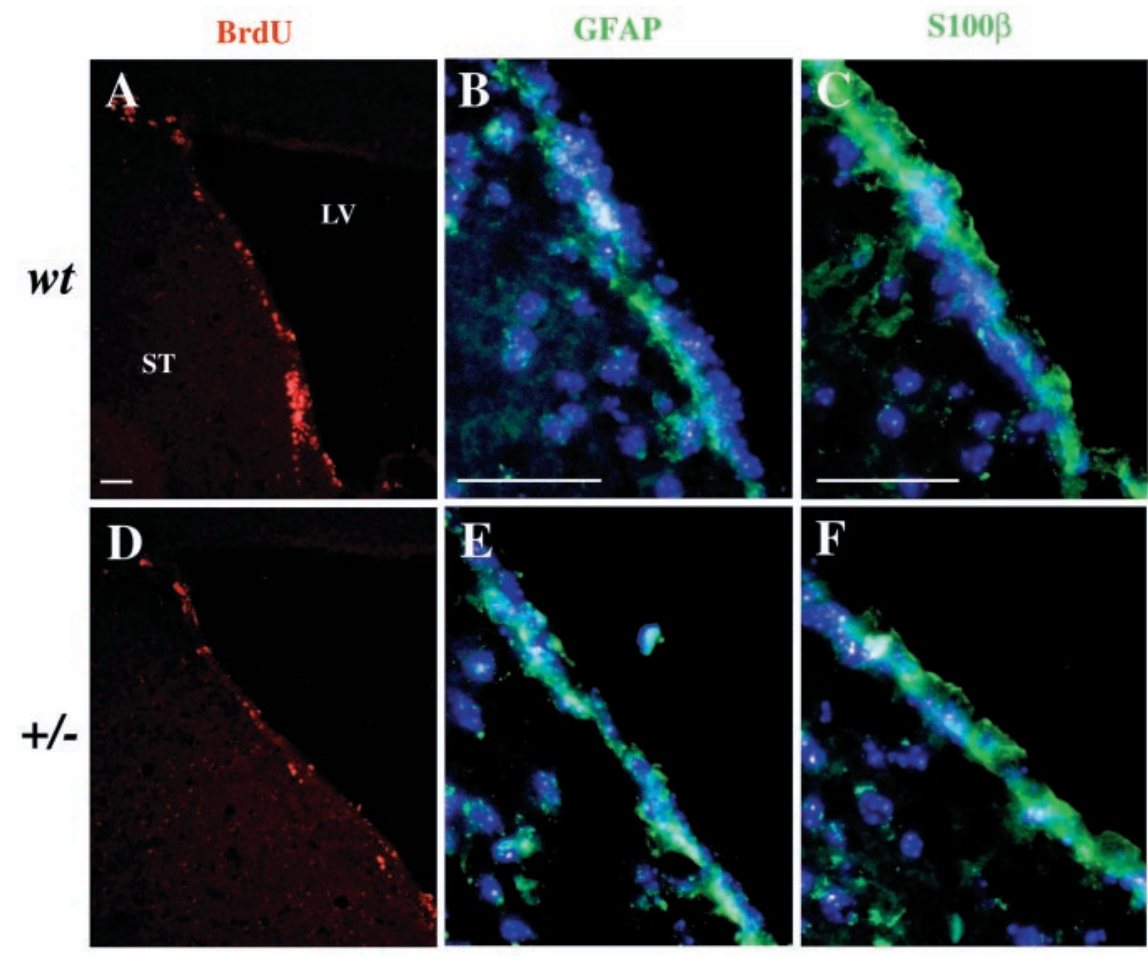

G

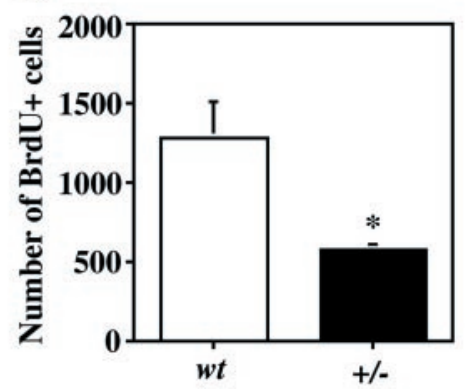

\section{H}

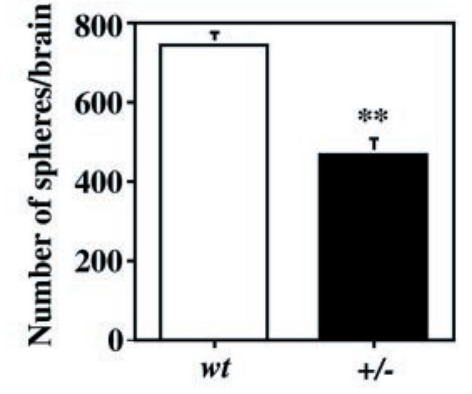

Figure 2. Reduction in the number of EGFresponsive neural stem cells and subependyma cell proliferation in the $L I F R^{+/-}$mouse forebrain. $A-F$, Immunofluorescence micrographs of coronal sections through the periventricular area of the adult forebrain lateral ventricle in a $w t$ and a $L I F R^{+/-}$mouse. The entire constitutively proliferating population was labeled by $10 \mathrm{hr}$ injections of $\mathrm{BrdU}$ (red). GFAPimmunoreactive cells in subependyma and $\mathrm{S} 100 \beta$ immunoreactive ependymal cells are visualized by FITC ( green) fluorescence. Each section was counterstained by Hoechst 33258 (blue). Scale bars, $50 \mu \mathrm{m}$. $G$, Quantification of the number of proliferating $(\mathrm{BrdU}+)$ cells in the subependyma of wild-type and LIFR $^{+/-}$mice (7- to 12-month-old females). The total number of BrdU+ cells in the subependyma between the rostral tip of the genu of the corpus callosum and the crossing of the anterior commissure from every 10 th section per brain were counted. $H$, Reduced generation of spheres from the periventricular area of the lateral ventricles in $L_{I F R^{+/-}}$(4- to 7-month-old female) mice. Lateral and medial aspects of the periventricular area were dissected from both hemispheres and cultured in EGF containing growth media. ${ }^{*} p<0.05$ and ${ }^{* *} p<0.01$ versus $w t$, two-tailed $t$ test $(n=3)$.

$\begin{aligned} & \text { Table 1. Reduction in the volume of the periventricular layers of the } \\
& \text { lateral ventricle in } \text { LIFR }^{+/} \text {adult mice }\end{aligned}$
\begin{tabular}{lll} 
Genotype & Mouse \# (age) & Average number of cell layers \pm SEM \\
\hline$w t$ & 1 (7 months) & $4.6 \pm 0.2$ \\
& 2 (7 months) & $4.7 \pm 0.2$ \\
& 3 (8 months) & $4.4 \pm 0.2$ \\
$+/-$ & 1 (8 months) & $3.4 \pm 0.2$ \\
& 2 (8 months) & $3.1 \pm 0.1$ \\
& 3 (12 months) & $3.1 \pm 0.1$
\end{tabular}

The number of layers in the thickest periventricular area of the mediolateral corner of the lateral ventricle between the rostral tip of the genu of the corpus callosum and the crossing of the anterior commissure from every 10th section (total 9 sections) per brain were counted. Hoechst nuclear staining was used for the counting.

by Nissl staining in five $0.04 \mathrm{~mm}^{2}$ fields in the fifth coronal section from the anterior end of the cortex. This suggests that the reduction of TH-containing neurons rather than reduced expression of TH protein expression itself underlies the reduction in the number of TH-immunoreactive cells. Thus, the reduction of the adult forebrain neural stem cell number was indeed correlated with the reduction in the number of $\mathrm{TH}$-immunoreactive interneurons of the olfactory bulb. We could not observe any gross morphological changes in the size or cytoarchitecture of the olfactory bulb in LIFR $^{+/-}$mice (data not shown).

\section{CNTF enhances self-renewal of EGF-responsive neural stem cells in vivo}

The maintenance of a neural stem cell could be supported by two distinct biological activities: cell survival and/or self-renewal. Because failure of either one would result in the extinction of neural stem cells, accompanied by the reduction of their differentiated progeny in the long-term, it is difficult to distinguish which activity is regulated by any one extrinsic factor. However, if such a factor supports survival of neural stem cells, a short exposure to the exogenous factor should not result in significant increases in stem cell number, because forebrain neural stem cells divide very slowly (average cell-cycle time is $\sim 15 \mathrm{~d}$ ) and maintain their number throughout adulthood (Tropepe et al., 1997; Morshead et al., 1998). Conversely, if the factor supports self-renewal of neural stem cells, exposure to the exogenous factor should increase the number of stem cells in a manner that is dependent on the frequency of cell division. To begin addressing the mechanism by which LIFR/gp130-mediated signaling supports the maintenance of forebrain neural stem cells, we infused CNTF into the lateral ventricles of adult mice for $6 \mathrm{~d}$, in the absence or presence of EGF. We chose CNTF to activate the gp130 signal- 


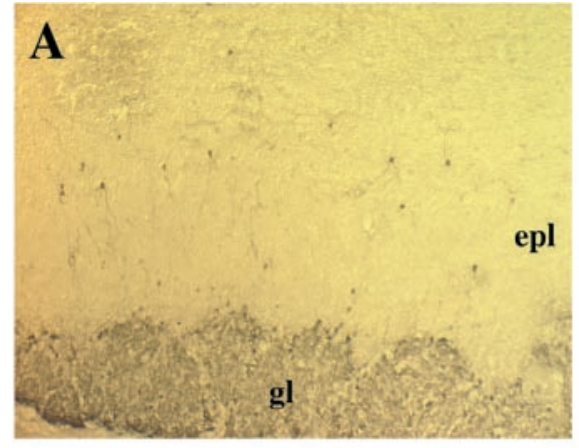

Figure 3. Reduction in the number of tyrosine hydroxylase-expressing interneurons in the olfactory bulbs of $L I F R^{+/-}$mice. TH immunohistochemistry of the coronal sections (30- $\mu$ m-thick) of olfactory bulbs from wild-type $(A)$ and $\operatorname{LIFR}^{+/-}(B)$ mice $(7-12$ months old) are shown. $D$, Quantification of the THimmunoreactive neurons in the periglomerular layer. ${ }^{*} p<0.01$ versus $w t$, two-tailed $t$ test $(n=3)$. All the TH-IR cells in the medial half of the olfactory bulb in five $30-\mu \mathrm{m}$-thick sections of every fifth section from the anterior end of the cortex illustrated in $C$ were counted. epl, External plexiform layer; $g l$, glomerular layer; $O B$, olfactory bulb; $o v$, olfactory ventricle.
C

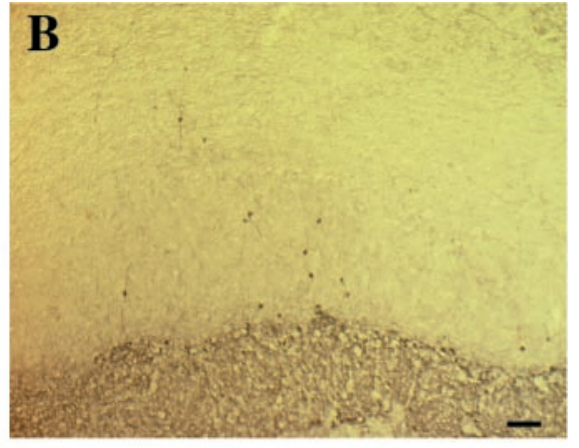

D
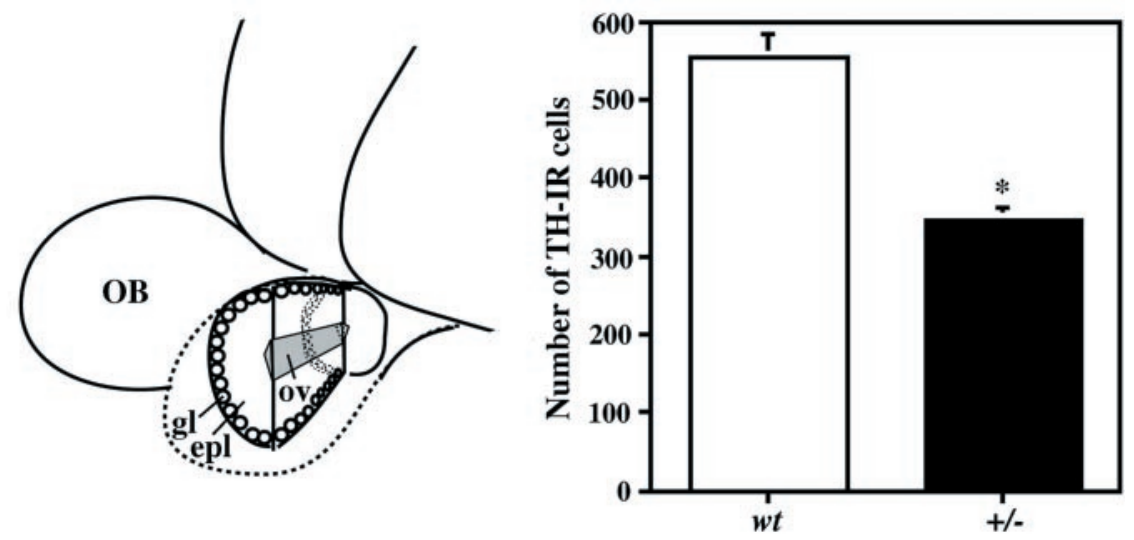

ing in subependymal cells, because the ligand and its specific receptor subunit CNTFR are expressed in the developing and adult CNS (Ip et al., 1993; Seniuk-Tatton et al., 1995). Particularly noteworthy is that CNTFR is predominantly expressed in a restricted manner in the adult forebrain periventricular area (Ip et al., 1993), where EGF-responsive neural stem cells reside (Morshead et al., 1994). Previous studies have shown that continuous infusion of EGF enhances proliferation and expansion of neural stem cells in vivo as well as in vitro (Craig et al., 1996; Kuhn et al., 1997). In the present study (Fig. 4) a $6 \mathrm{~d}$ infusion of CNTF into the lateral ventricles resulted in a slight increase $(24 \% ; p=$ 0.029 vs vehicle infusion; $n=3$ ) in the number of subsequently derived EGF-responsive sphere-forming cells. When the in vivo proliferation of neural stem cells were enhanced by the infusion of EGF, co-inf usion of CNTF resulted in a much greater increase $(41 \% ; p=0.0033 ; n=4)$ in the number of subsequently derived sphere-forming cells. These results suggest that CNTFR/LIFR/ gp130-mediated signaling supports self-renewal of neural stem cells rather than their survival, given that the actions of CNTF were greater (41 vs 24\%) when the frequency of neural stem cell proliferation was increased by concomitant exposure to EGF.

\section{CNTF enhances the expansion of EGF-responsive neural stem cells in vitro}

The enhancement of neural stem cell self-renewal may be a result of either increased proliferation or an inhibition of lineage commitment-restriction during proliferation. Because there are no unambiguous markers for neural stem cells, such analyses of the mechanisms of CNTF actions would be difficult to examine in vivo. To determine how CNTF supports the self-renewal of neural stem cells, we analyzed EGF-responsive stem cells in vitro in the presence of EGF plus CNTF or EGF alone. We used

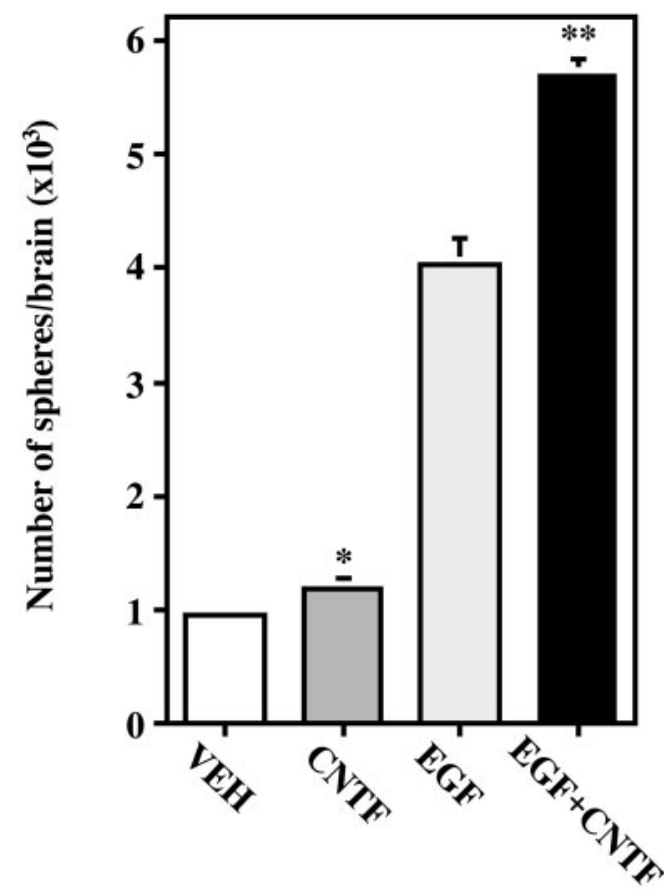

Figure 4. CNTF enhances the expansion of EGF-responsive neural stem cells in vivo. Sixteen 8-week-old CD-1 mice were inf used with the following: vehicle alone, rat recombinant CNTF $(33 \mu \mathrm{g} / \mathrm{ml})$, human recombinant EGF $(33 \mu \mathrm{g} / \mathrm{ml})$, or EGF plus CNTF into the right lateral ventricle for 6 consecutive days, followed by sphere formation assay as described in Materials and Methods and legend to Figure 2 . ${ }^{*} p<0.05$ versus VEH and ${ }^{* *} p<0.01$ versus EGF, two-tailed $t$ test $(n=3$ or 4$)$. 
primary cultured spheres from E14 forebrain ganglionic eminences (striatal-pallidal primordia), grown in the EGF-containing growth media, as an enriched source of EGF-responsive neural stem cells for the following experiments, unless otherwise noted. The characteristics of E14 neural stem cells expanded in vitro are virtually identical to those derived from the adult forebrain, regarding self-renewal expansion and multipotency (Reynolds and Weiss, 1992, 1996). The ability to easily generate large numbers of enriched neural stem cells is why we chose the embryonic counterparts to ascertain the mechanism of action of CNTF (presumably not specific in vitro to adult neural stem cells) on the expansion of EGF-responsive neural stem cells. Also, because primary cultures initially contain small number of neural stem cells $(<0.1 \%)$ and a large number of differentiated neurons, we used an enriched (relatively purified to $10-20 \%$ neural stem cells; Reynolds and Weiss, 1996) population selectively expanded in vitro in the presence of EGF to minimize indirect effects. The basic protocol is illustrated in Figure 5.

Single-cell suspensions (derived from spheres generated in primary culture) were used as the source of neural stem cells and plated at a density of $5 \times 10^{4}$ cells $/ \mathrm{ml}$ or at clonal density of 150 cells/ml). These cells generated P1 spheres (Fig. 5) during a further $7 \mathrm{~d}$ in vitro, in EGF-containing culture medium, in the absence or presence of CNTF $(20 \mathrm{ng} / \mathrm{ml})$. No P1 spheres formed in the presence of CNTF alone (data not shown). There was no difference in the absolute number of P1 spheres generated, at clonal density, in the presence of EGF compared with EGF plus CNTF (Fig. 6A). This confirms the contention that CNTF does not act as a neural stem cell survival factor. Furthermore, an examination of BrdU incorporation (Fig. $6 B$ ) or total cell number (Fig. 6C) within P1 spheres found no significant difference between those generated in EGF compared with those grown in EGF plus CNTF. These results suggest that the general proliferation and survival of cells within P1 spheres is not affected by the presence of CNTF.

To ascertain whether CNTF could regulate the expansion of neural stem cells in vitro as we had observed in vivo and to determine if continuous exposure to the cytokine was necessary, we generated P1 spheres in the absence or presence of CNTF for various periods of time (constitutively, for the full $7 \mathrm{~d}$; transient, for the first $3 \mathrm{~d}$; or delayed, for the last $4 \mathrm{~d}$ ). To quantify the possible expansion actions of CNTF, the P1 spheres from the different culture conditions were dissociated individually in 96 well plates and were allowed to form P2 spheres (Fig. 5) in culture medium containing EGF only (no CNTF) for $7 \mathrm{~d}$. After $7 \mathrm{~d}$ in vitro, the numbers of $\mathrm{P} 2$ spheres per well were counted. As shown in Figure $6 D$, exposure of neural stem cells to $\mathrm{CNTF}$ during the formation of $\mathrm{P} 1$ spheres resulted in a significant increase in the number of $\mathrm{P} 2$ spheres derived from a single P1 sphere. A 59\% increase was observed with P1 spheres that had been generated with a constitutive exposure to CNTF, whereas either transient (first 3 d) or delayed (last $4 \mathrm{~d}$ ) exposure were somewhat more effective (141 and $168 \%$ increases, respectively). However, when dissociates from P1 spheres were exposed to CNTF only for the first $24 \mathrm{hr}$ (before the first cell division), we did not observe a significant increase in the number of $\mathrm{P} 2$ spheres (data not shown). These results suggest that CNTF actions on the expansion of EGF-responsive neural stem cells require cell division and/or cell-cell interaction. To confirm the results obtained by the analysis of individual spheres described above and to gain an appreciation of the actual numbers of sphereforming cells, we performed the following experiments. Dissociated P1 spheres, grown in the presence of EGF alone or EGF plus

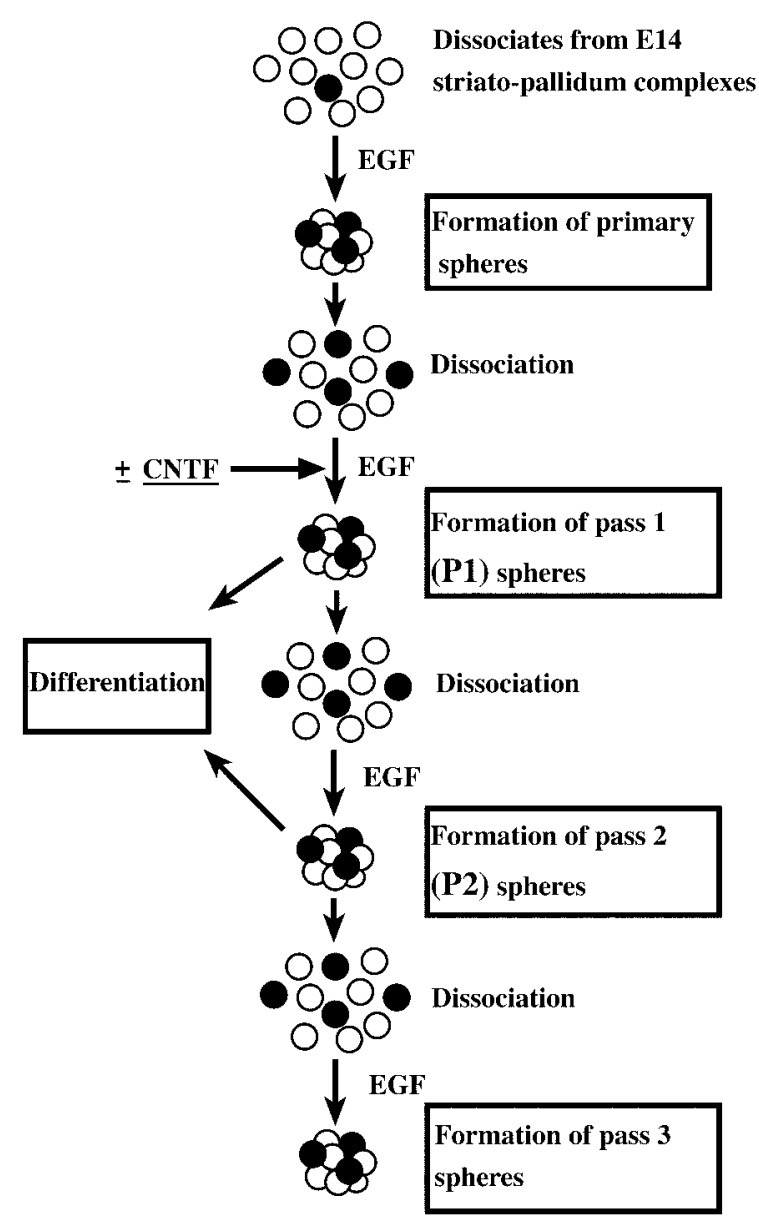

Figure 5. The basic experimental protocol for the in vitro assessment of neural stem cell activity in this study. A neural stem cell (black circle) can be expanded by the formation of a clonally derived cell cluster termed a sphere in EGF-containing growth medium. Neural stem cells are thus enriched by generation of primary spheres from dissociates of the E14 striato-pallidum complexes. These primary spheres containing a number of neural stem cells ( $\sim 20 \%$; Reynolds and Weiss, 1996) are dissociated and cultured in populations $\left(5 \times 10^{4}\right.$ cells $\left./ \mathrm{ml}\right)$ for $7 \mathrm{~d}$ or clonally $(150$ cells/ml per $9.6 \mathrm{~cm}^{2}$ ) for $12-13 \mathrm{~d}$, in EGF or EGF plus CNTF-containing medium, to obtain the next generation of spheres (P1). P1 spheres are then assessed for the following: (1) their expandability by dissociation and generation of secondary sphere (P2) formation and (2) multipotency by plating and allowing them to differentiate for $7 \mathrm{~d}$ in the absence of mitogens or cytokines. P2 spheres from clonally derived P1 spheres are similarly assessed for their expandability (to form P3 spheres) and multipotency.

CNTF, were plated at clonal density in the presence of EGF only. After $7 \mathrm{~d}$ we counted the number of $\mathrm{P} 2$ spheres generated, relative to the total number of cells plated. Similar to our results with single sphere analysis, we found that the P1 spheres grown in EGF plus CNTF produced $70 \%$ more P2 spheres $(9.7 \pm 1.8 \%$ of total cells $)$ than those grown in EGF only $(5.7 \pm 1.8 \%$ of total cells; $p=$ $0.0064 ; n=3)$. Taken together, these results suggest that CNTF enhances self-renewal of EGF-responsive neural stem cells (production of secondary neural stem cells) without affecting cell proliferation or survival.

\section{CNTF increases neural stem cell number by suppressing their lineage restriction to glial progenitors}

In an effort to understand how CNTF enhances expansion of neural stem cells, we performed an examination of single P1 

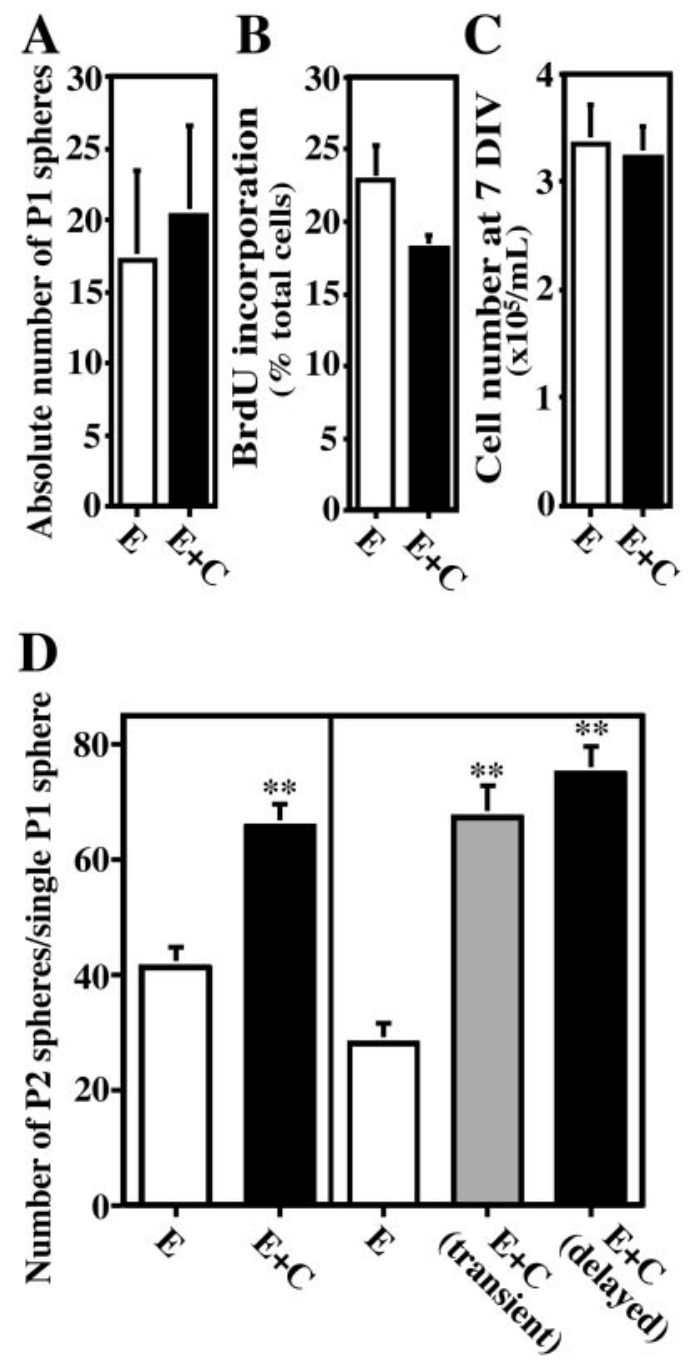

Figure 6. CNTF enhances expansion of EGF-responsive neural stem cells in vitro. Primary EGF-derived spheres, which contain stem cells from E14 ganglionic eminences, were dissociated into a single cell suspension and plated onto 6-well plates or $25 \mathrm{~cm}^{2}$ flasks at a density of 150 or $5 \times$ $10^{4}$ cells $/ \mathrm{ml}$, respectively. These cells were grown and formed $\mathrm{P} 1$ spheres in the presence of either EGF $(20 \mathrm{ng} / \mathrm{ml})$ or EGF plus CNTF $(20 \mathrm{ng} / \mathrm{ml}$ each) for $7 \mathrm{~d}$ in vitro. $A$, The effect of CNTF on the survival of EGFresponsive neural stem cells was examined. The absolute number of P1 EGF-generated spheres was compared with the absolute number of P1 EGF plus CNTF-generated spheres, at a density of 150 cells/ml per 9.6 $\mathrm{cm}^{2}$ (two-tailed Student's $t$ test; $n=5$ independent cultures). B, BrdU labeling was performed to examine the effect of CNTF on the proliferation of EGF-responsive neural stem cells. One micromolar BrdU was administrated into P1 cultures at $3 \mathrm{~d}$ in vitro. Twenty-four hours later, populations of spheres were mechanically dissociated and plated onto poly-L-ornithine-coated coverslips at a density of $1 \times 10^{5} \mathrm{cell} / \mathrm{cm}^{2}$. The cells were processed for BrdU immunocytochemistry $2 \mathrm{hr}$ after plating (two-tailed Student's $t$ test; $n=4$ independent cultures). $C$, Total cell numbers at $7 \mathrm{~d}$ in vitro. Population of $7 \mathrm{~d}$ in vitro P1 EGF-generated spheres and P1 EGF plus CNTF-generated spheres were trypsinized and mechanically dissociated to count the number of cells (two-tailed Student's $t$ test; $n=4$ independent cultures). $D$, During the growth of P1 spheres with EGF, concomitant exposure to CNTF was constitutive (full $7 \mathrm{~d}$ ), transient (first $3 \mathrm{~d}$ ), or delayed (last $4 \mathrm{~d}$ ). Two hundred micrometer diameter P1 spheres were then exposed to $0.25 \%$ trypsin-EDTA solution for $5 \mathrm{~min}$ followed by quenching the enzymatic digestion by trypsin inhibitor $(1 \mathrm{mg} / \mathrm{ml}$; Sigma) containing media and then transferred individually into 96-well plates filled with EGF-containing growth media. Each P1 sphere was mechanically dissociated into a single cell suspension using micropipettes and cultured for another $7 \mathrm{~d}$. Then resultant P2 spheres were counted, as their number assesses expansion of neural stem spheres grown at clonal density. Single-cell suspensions (Fig. 5) were plated at clonal density $\left(<15\right.$ cells $\left./ \mathrm{cm}^{2}\right)$ and grown into P1 spheres as before in EGF-containing culture medium in the absence or presence of CNTF. P1 sphere formation under these clonal density experimental conditions required 12-14 d. Virtually all P1 spheres grown at this density should be clonally derived (Tropepe et al., 1999). The media in all culture conditions were replaced with EGF-containing culture medium (no CNTF) at $6 \mathrm{~d}$ in vitro, so that growing $\mathrm{P} 1$ spheres were exposed to CNTF only transiently. The resultant P1 spheres were individually dissociated into EGF alone to form P2 spheres to examine self-renewal and expansion. Also, individual P1 spheres were allowed to differentiate intact for $7 \mathrm{~d}$ to examine their multipotent phenotype. As shown in the left-hand column of Table 2, when P1 spheres that had been generated in the presence of EGF plus CNTF were dissociated and replated in EGF alone, a significantly greater number of $\mathrm{P} 2$ spheres ( $22 \pm 2 \mathrm{P} 2$ spheres/P1 sphere) were produced when compared with $\mathrm{P} 1$ spheres grown in EGF alone and subcultured into $\mathrm{P} 2$ spheres in EGF alone $(13 \pm 1 \mathrm{P} 2$ spheres/P1 sphere). This is similar to what was observed in the high-density cultures (Fig. 6D), suggesting that CNTF acts directly on neural stem cells and/or through cell-cell interactions within individual spheres. The difference in the average number of secondary spheres from a single P1 sphere, grown in EGF alone, between high-density cultures (Fig. 6D) and clonal cultures (Table 2) may be attributable to differences in the plating density and/or culture periods. On the other hand, the percentage of P1 spheres that were capable of expansion (produce more than one P2 sphere) when dissociated and plated in EGF alone was not different when comparing P1 EGF spheres $(85.9 \pm 4.6 \%)$ and P1 EGF plus CNTF $(97.9 \pm 1.0 \%)$ spheres. Moreover, when intact P1 spheres were examined for the presence of neurons, astrocytes, and oligodendrocytes ( $\mathrm{N}$ plus A plus $\mathrm{O}$ ) again, no difference was observed in the percentage of P1 EGF spheres (78.2 \pm $4.1 \%)$ and P1 EGF plus CNTF spheres $(85.3 \pm 1.5 \%)$ that contained all three CNS cell types. Thus, P1 spheres generated in EGF plus CNTF produced a greater number of secondary neural stem cells (P2 spheres) than those generated in EGF alone, whereas their ability to produce the three principal differentiated cell types remained unaffected.

Two possible mechanisms (at least) could explain the increased number of secondary stem cells (increased P2 spheres/single P1 sphere) caused by the presence of CNTF. Either CNTF enhances the numbers of symmetric cell divisions of neural stem cells within a growing P1 sphere or CNTF prevents the lineage restriction of newly generated neural stem cells (within a P1 sphere) to a more differentiated (less expandable, less multipotent) phenotype. In both scenarios, one would see a greater number of P2 spheres (secondary neural stem cells) generated from a single P1 sphere. However, if this increase was simply attributable to an increased number of symmetric cell divisions, then one would predict that the phenotype of P2 spheres (expansion and multipotency) should not be different, whether derived from P1 EGF spheres or P1 EGF plus CNTF spheres. On the other hand, should CNTF prevent the lineage restriction of newly generated multipotent cells to a more differentiated phenotype,

cells proliferated in each condition. ${ }^{* *} p<0.01$ versus control EGF cultures, Tukey's honestly significant difference (HSD) test $(n=120$ from four independent cultures). Note that the media in all the cultures shown in the right panel were washed out and replaced at $3 \mathrm{~d}$ in vitro. 
Table 2. Clonal analysis suggests that CNTF suppresses a lineage restriction of EGF-responsive neural stem cells to glial progenitors

$$
\text { P1 spheres (clonal density-derived) }
$$

Assay
No. of P2 spheres from a single P1 sphere
Spheres that expand in EGF alone $(\%)$
Phenotypes of spheres (\% total spheres)
$\mathrm{N}+\mathrm{A}+\mathrm{O}$
$\mathrm{N}+\mathrm{A}$
$\mathrm{A}+\mathrm{O}$

\begin{tabular}{rr}
\multicolumn{1}{c}{ EGF } & EGF + C \\
$13 \pm 1$ & $22 \pm 2^{* * *}$ \\
$85.9 \pm 4.6$ & $97.9 \pm 1.0$ \\
& \\
$78.2 \pm 4.1$ & $85.3 \pm 1.5$ \\
$5.2 \pm 2.6$ & $4.0 \pm 2.1$ \\
$14.3 \pm 1.3$ & $10.2 \pm 0.7$ \\
$2.3 \pm 1.2$ & $0.4 \pm 0.4$
\end{tabular}

P2 spheres (derived from single P1 spheres)

\begin{tabular}{ll}
\hline EGF & EGF + CNTF \\
$\downarrow$ & $\downarrow$ \\
EGF & EGF \\
\hline
\end{tabular}

Not applicable

Not applicable
$47.9 \pm 4.8$

$71.3 \pm 6.0^{*}$

$62.5 \pm 6.7^{* * *}$

$4.4 \pm 0.5$

$30.0 \pm 4.2^{* * *}$

$87.4 \pm 2.7^{*}$

$4.6 \pm 2.8$

$7.2 \pm 2.2^{*}$

$3.1 \pm 2.5$

$0.8 \pm 0.8$

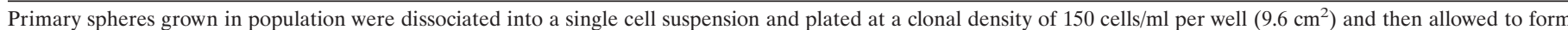

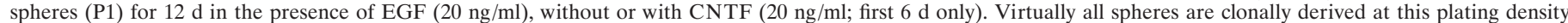

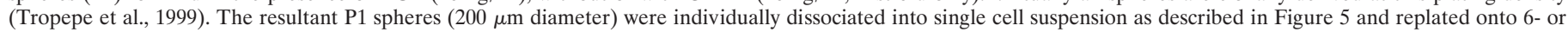

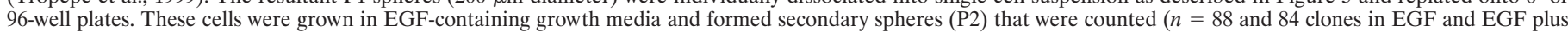

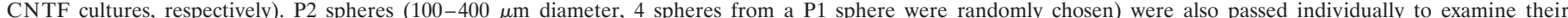

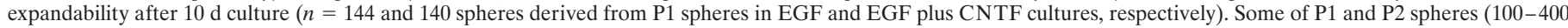

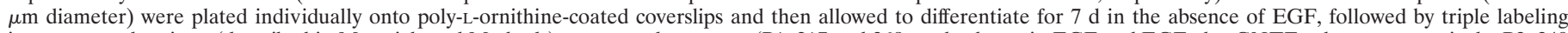

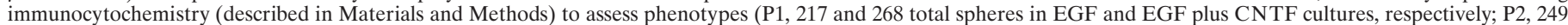

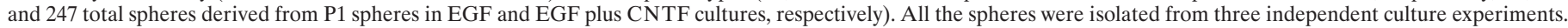
$\mathrm{N}$, neuron; A, astrocyte; O, oligodendrocyte. Data presented represent the mean \pm SEM from three independent culture experiments.

${ }^{*} p<0.05 ; *{ }^{*} p<0.01$ versus EGF alone; ${ }^{* *} p<0.05$ versus P1 (Tukey HSD test for the number of spheres and Mann-Whitney $U$ test for percentages).

P2 spheres derived from P1 EGF plus CNTF spheres should be more expandable and multipotent than $\mathrm{P} 2$ spheres derived from P1 EGF spheres. We tested this by examining the expansion and multipotency of P2 spheres, derived (in EGF alone) from single P1 EGF spheres or single P1 EGF plus CNTF spheres (righthand column of Table 2). P2 spheres derived from EGF plus CNTF spheres could expand $(71.3 \pm 6.0 \%)$ to a greater extent than P2 spheres derived from EGF spheres $(47.9 \pm 4.8 \% ; p<$ 0.05). Also, P2 spheres derived from EGF plus CNTF spheres were multipotent $(87.4 \pm 2.7 \%)$ to a greater extent than P2 spheres derived from EGF spheres $(62.5 \pm 6.7 \% ; p<0.05)$. At the same time, P2 spheres derived from EGF plus CNTF spheres were astrocyte- and oligodendrocyte-producing (A plus O) only $(7.2 \pm 2.2 \%)$ to a lesser extent than P2 spheres derived from EGF spheres $(30.0 \pm 4.2 \%$; $p<0.05)$.

Taken together, these results show that when subcultured as individual spheres (P1 $\rightarrow$ P2) (Fig. 5), a proportion of EGFresponsive neural stem cells becomes restricted to glial progenitors. However, if exposed to CNTF during the formation of P1 spheres, the lineage restriction of a significant number of the EGF-responsive neural stem cells is suppressed, resulting in enhanced self-renewal and expansion in vitro.

\section{CNTF enhances astrocyte differentiation but not commitment}

It has been proposed that CNTFR/LIFR/gp130 signaling instructs stem cells to differentiate into astrocytes and inhibits neurogenesis (Johe et al., 1996; Bonni et al., 1997; Koblar et al., 1998). In contrast, we observed a CNTF-induced increase in the number of P2 sphere-forming neural stem cells (approximately twofold) during the proliferation of P1 neural stem cells (as shown above). The majority of cells in spheres are themselves not sphere-forming neural stem cells (Reynolds and Weiss, 1996), suggesting that the fate of most cells is more restricted. To understand the exact effect of CNTF on lineage commitment and differentiation of astrocytes during neural stem cell proliferation, we assessed the generation of astrocytes by EGF-responsive neural stem cells exposed to CNTF for different periods of time. First, we examined astrocyte production within growing spheres over time. Single cell suspensions (from primary EGF-derived spheres) were cultured in population in EGF-containing culture media in the absence or presence of CNTF for 3,5 , or $7 \mathrm{~d}$ in vitro. The resultant spheres were dissociated and then differentiated on poly-L-ornithine coated coverslips for $7 \mathrm{~d}$ to obtain full differentiation, followed by immunocytochemistry and cell counting. Surprisingly, we found that administration of CNTF during the proliferation of neural stem cells did not change astrocyte production in resultant spheres (Fig. 7A). The number of astrocytes, characterized by GFAP expression and astrocytic morphology, was consistent at $\sim 60 \%$ of total cell number in both conditions throughout the culture period. We then examined the effect of CNTF on astrocyte differentiation. This was an effort to reconcile our findings with those previously reported (Johe et al., 1996; Bonni et al., 1997; Bartlett et al., 1998). Normally, GFAPexpressing cells are first detected $3 \mathrm{~d}$ after plating of spheres in differentiation conditions (data not shown). When cells were exposed to CNTF constitutively for $7 \mathrm{~d}$ during the growth of spheres, then dissociated and allowed to differentiate, we observed a significantly greater number of GFAP-expressing astrocytes just 2 hr after plating (Fig. $7 B$ ). On the other hand, there was no significant increase in GFAP-expressing cells when growing spheres were exposed to CNTF transiently (for the first $3 \mathrm{~d}$ ), despite both these conditions giving the same number of secondary neural stem cells. These results suggest that CNTF enhances differentiation of precursors already committed to the astroglial lineage. On the other hand, our data suggest that CNTF does not promote uncommitted precursors, generated during the proliferation of EGF-responsive forebrain neural stem cells, to the astroglial lineage.

\section{DISCUSSION}

\section{CNTFR/LIFR/gp130 mediated signaling supports self- renewal of neural stem cells}

The results of previous studies suggest that forebrain neural stem cells initially expand their numbers during early development, these numbers are reduced during the early postnatal period, and then maintained without any further reduction into adulthood 

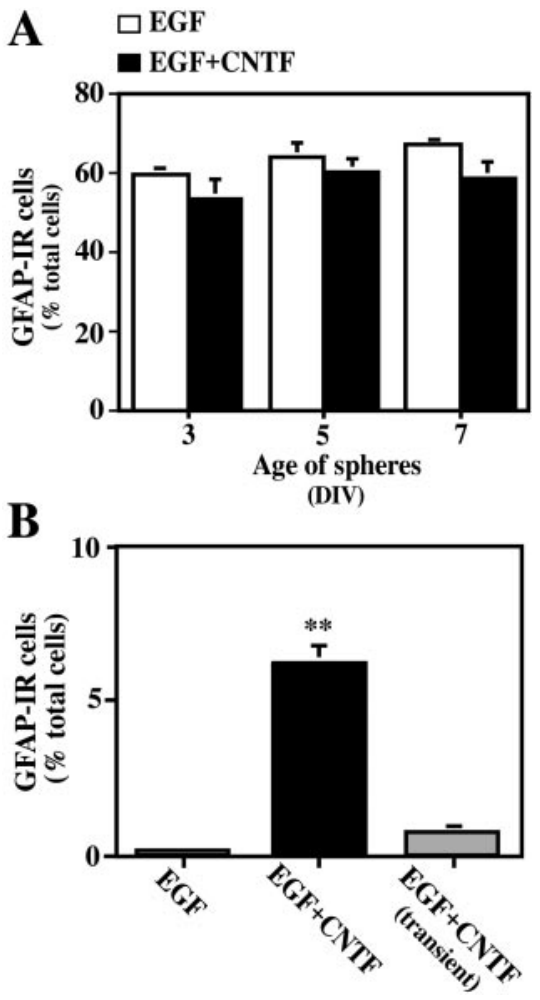

Figure 7. Effect of CNTF on astrocyte generation within spheres. $A$, Populations of spheres grown in the presence of either EGF or EGF plus CNTF (as described in Fig. 6) were allowed to differentiate at 3, 5, or $7 \mathrm{~d}$ in vitro. After mechanical dissociation into a single cell suspension, cells were plated onto poly-L-ornithine-coated coverslips in the EGF and CNTF-free media (see Materials and Methods) at a density of $1 \times 10^{5}$ cells $/ \mathrm{cm}^{2}$ and cultured a further $7 \mathrm{~d}$. Fully differentiated cells were fixed and processed for GFAP immunocytochemistry to assess astrocyte generation by neural stem cells. $B$, CNTF was administrated constitutively, first $3 \mathrm{~d}$ (transient) or last $4 \mathrm{~d}$ (delayed) during growth of spheres (as described in Fig. $6 D$ ) and then dissociated and plated as described in $A$. Two hours after, plated cells were fixed and processed for GFAP immunocytochemistry. ${ }^{* *} p<0.01$ versus control EGF cultures, Tukey's HSD test $(n=4)$.

(Tropepe et al., 1997, 1999; Morshead et al., 1998; Martens et al., 2000). Because forebrain neural stem cells appear to be localized principally to the periventricular area, the microenvironment in this area could be important in maintaining stem cell number. In this study, we found limited long-term self-renewal and expansion of EGF-responsive stem cells derived from E14 IIFR $^{-1-}$ mice (Fig. 1) and a reduction in the number of neural stem cells and their progeny (Figs. 2, 3) in the forebrain of adult mice with a $50 \%$ reduction in LIFR expression $\left(\right.$ LIFR $^{+/-}$mouse). This suggests that there is a requirement for LIFR/gp130-mediated signaling in the maintenance of forebrain EGF-responsive neural stem cells. The first question that arises is how this signaling supports the maintenance of these neural stem cells. The maintenance of a neural stem cell could be supported by two distinct biological activities: cell survival and/or self-renewal. To address this issue, we focused on an examination of CNTF actions, because of its receptor (CNTFR) being expressed in a restricted manner in the developing and adult perventricular area (Ip et al., 1993), where EGF-responsive neural stem cells reside (Morshead et al., 1994). Our in vivo and in vitro studies suggest that CNTF enhances self-renewal of stem cells but not their survival. First, a $6 \mathrm{~d}$ inf usion of CNTF into the lateral ventricle of the adult mouse forebrain resulted in a slight increase $(24 \%)$ in the number of sphere-forming cells (Fig. 4). The fact that this action is significantly augmented (up to $41 \%$ ) when the proliferation of neural stem cells was stimulated by the infusion of EGF suggests that CNTF does not support survival but rather self-renewal of neural stem cells. If CNTF was merely acting as a survival factor, one would expect that the relative increase in neural stem cell number should be similar, with or without the actions of EGF. Second, our in vitro analyses also showed no evidence suggesting CNTF is a survival factor to neural stem cells. The fact that the absolute number of P1 spheres generated by EGF plus CNTF (Fig. 6A) is not different than that generated by EGF alone (as opposed to the differences in the number of P2 neural stem cells within the generated P1 spheres) (Fig. 6D, Table 2) most directly argues against an action of CNTF on survival. Thus, the reduction in the number of neural stem cells in $\mathrm{LIFR}^{+/-}$mice is likely to be caused by diminished self-renewal. It is still possible that environmental changes caused by the reduction in LIFR expression might have affected neural stem cell survival. In fact, the number of cell layers in the periventricular area was significantly reduced, which might have in turn modified the cytoarchitectural and chemical environment. Furthermore, there is a possibility that the neural stem cells might have simply reduced their responsiveness to mitogens such as EGF and FGF-2, which should have resulted in reduced sphere formation in vitro. However, the fact that CNTF does not affect cell proliferation but rather the number of secondary neural stem cells within spheres grown in the presence of EGF in vitro suggests that this is not likely to be the case. Thus, taking both in vitro and in vivo observations into account, CNTFR/LIFR/gp130-mediated signaling appears to support self-renewal of EGF-responsive neural stem cells rather than their survival.

\section{Maintenance of the neural stem cell state}

The next issue arising from our results is how CNTFR/LIFR/ gp130-mediated signaling supports self-renewal of neural stem cells. It has been proposed that EGFR-mediated signaling biases late cortical and retinal progenitor cells toward glial lineages, in particular astrocytes, depending on the receptor and ligand concentration (Burrows et al., 1997), although in that study it was not clear how the EGFR signal influenced fate choice. When examined at clonal density (Table 2), EGF-responsive neural stem cells exhibited a gradual, time-dependent lineage restriction to glial progenitors, a process accompanied by a limitation of their expandability. It seems as though CNTFR/LIFR/gp130-mediated signaling antagonizes this process, resulting in the enhanced self-renewal of neural stem cells. In turn, this suggests that the EGFR signal may instruct EGF-responsive neural stem cells toward the glial lineage. On the other hand, it has been shown that the postnatal brain of the $E G F R^{-/-}$mouse exhibited reduced proliferation and delayed differentiation of astrocytes yet was cytoarchitecturally normal at birth (Kornblum et al., 1998; Sibilia et al., 1998). Also, an in vitro study using EGFR-specific tyrosine kinase inhibitor suggested that the increased bias toward glial differentiation during development does not depend on EGFR signaling (Zhu et al., 2000). Taken together, it may be that the EGFR signal merely increases the frequency of deterministic fate restriction of EGF-responsive neural stem cells to the glial lineage by an increased number of cell divisions. If this is the case, CNTFR/LIFR/gp130-mediated signaling could support selfrenewal of EGF-responsive neural stem cells by suppressing the lineage restriction to glial progenitor cells. In other words, this 
signal is required for the maintenance of the neural stem cell state.

Several studies have suggested that LIFR/gp130-mediated signaling instructs neural stem cells to the astrocytic lineage (Johe et al., 1996; Bonni et al., 1997; Bartlett et al., 1998), possibly as a result of a reduction in the number of differentiated neurons produced. However, none of those studies showed exactly which type of cells differentiated into astrocytes and how reduced neurogenesis appeared (e.g., fate change or suppression of differentiation) in response to gp130 signaling. Here, we found that CNTF enhances differentiation of astrocyte precursors (Fig. 7) but not the commitment of neural stem cells to an astrocytic fate. A recent report (Molne et al., 2000) that shows that early cortical precursors [which only include neural stem cells and neuroblasts but few glial precursors (Davis and Temple, 1994)] do not undergo LIF-mediated astrocytic differentiation, supports our observations. An alternative explanation is that some of the previous observations may be attributable to LIFR/gp130 signal enhancing GFAP gene and protein expression in neural stem cells and/or multipotent progenitors. Indeed, we have observed enhanced GFAP expression within spheres growing in the presence of EGF plus CNTF (data not shown). This may not be surprising given that GFAP is expressed in neural stem cells of the adult subependyma (Doetsch et al., 1999). In fact, GFAP gene expression is directly regulated by STAT3 (Bonni et al., 1997; Nakashima et al., 1999), a downstream intracellular mediator of the LIFR/gp130 signal.

Analysis of neural stem cell number and their proliferative cell-producing activities in vivo, in LIFR-deficient mice, indicates that the requirement of this signaling system for the maintenance of neural stem cells is relevant in the postnatal to adult period rather than during embryogenesis. There are a couple of possible explanations for this observation. First, some other signaling may compensate for the function of LIFR/gp130 signaling and may principally contribute to the self-renewal of more primitive neural stem cells that generate mostly neurons (Qian et al. 2000). In this case, it is likely not a different gp130 complex-mediated signaling, because there is no significant change in the number of neural stem cells in gp130-deficient mice at E14 (Ohtani et al., 2000). In fact, such an alternative maintenance pathway has been proposed for embryonic stem cells that can be maintained in the absence of LIF and the LIFR (Dani et al., 1998). Second, EGFresponsive neural stem cell to glial progenitor lineage restriction model, as proposed above, could be applicable in explaining this stage dependent effect of LIFR/gp130 signaling. The peak period of gliogenesis, perhaps largely contributed to by EGF-responsive neural stem cells exclusively localized in the subependyma (Martens et al., 2000), takes place primarily in the early postnatal period (Altman, 1966). During this period, the subependyma predominantly contains glial-restricted progenitors (Levison and Goldman, 1993; Levison et al., 1993; Young and Levison, 1996). If the lineage restriction of neural stem cells to glial progenitors occurs exclusively during this period and if LIFR/gp130 signaling suppresses that lineage restriction specifically, the significant effect of reduced expression of LIFR should not appear before the peak period of gliogenesis. We have summarized our hypothesis regarding when and how LIFR/gp130 signaling regulates the maintenance of neural stem cells in Figure 8. To ascertain precisely when and how the actions of the LIFR/gp130 signal on self-renewal of neural stem cells begins, conditional timed disruption (complete) of LIFR or gp130 needs to be done. This is particularly so, given that (1) the difference in the number of

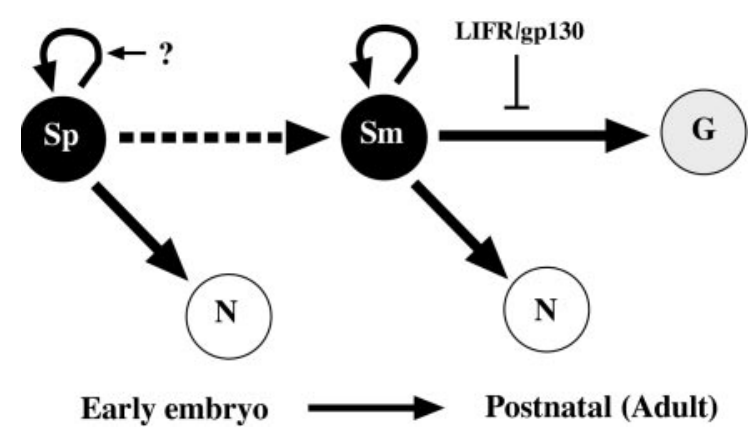

Figure 8. Possible mechanism of action of LIFR/gp130-mediated signaling on the maintenance of neural stem cells during forebrain development. Primitive neural stem cells $(S p)$ may principally generate neurons $(N)$ during early embryonic development and then begin the generation of glia $(G)$ after their maturation (Qian et al., 2000) in late embryogenesis. Some unknown factors (?) likely support the self-renewal of primitive neural stem cells. The peak period of the gliogenesis may be in the early postnatal period (Altman, 1966) after the expansion of the mature multipotent neural stem cells $(\mathrm{Sm})$. The contribution of LIFR/gp130 signaling to self-renewal and maintenance likely appears after maturation of neural stem cells. Specifically, the LIFR/gp130 signal is proposed to inhibit the lineage restriction of mature multipotent neural stem cells to the glial lineage during the early postnatal period to adulthood.

neural stem cells in adult $\mathrm{LIFR}^{+/-}$brain is only $37 \%$ of wild-type littermates and (2) the number of neural stem cells robustly decrease during postnatal maturation of the forebrain (from $\sim 200,000$ per forebrain at P0, when no difference is seen with LIFR disruption, to $<1000$ in the mature adult). These types of conditional, timed disruptions would also reveal detailed mechanisms, which could explain the stage-dependent responsiveness of neural stem cells to LIFR/gp130-mediated signaling and its correlation to the transition from neurogenesis to gliogenesis during CNS development.

\section{Function of adult forebrain neural stem cells}

In postnatal rodents, neuronal precursors generated by neural stem cells of the lateral ventricle migrate into the olfactory bulb and differentiate into GABAergic and dopaminergic interneurons in the granular and periglomerular layers (Lois and AlvarezBuylla, 1994; Morshead et al., 1994; Betarbet et al., 1996). Therefore, the function of these newly generated interneurons may in turn reflect, in part, the function of the adult neural stem cells. Recently, by analyzing $N C A M$-deficient mice that have a defect in the rostral migration of neuronal precursors generated in the subependyma at early postnatal days and adulthood (Tomasiewicz et al., 1993; Cremer et al., 1994; Chazal et al., 2000), it was found that the newly generated interneurons located in the granule cell layer may be involved in odor discrimination (Gheusi et al., 2000). However, it is still unclear whether the TH-positive interneurons located in the periglomerular layer are involved in olfactory discrimination, because it has not been determined whether their numbers are reduced in NCAM-deficient mice. In the present study, we observed a significant reduction in the number of TH-positive interneurons in the olfactory bulb of LIFR-deficient heterozygotes. It is reasonable to conclude that the reduction of neural stem cell number and the constitutively proliferative population contributed to the reduction of $\mathrm{TH}$ positive neurons in the olfactory bulb. We cannot rule out, however, that the reduction of TH-positive neurons could be, in part, a result of the migration or survival of the neurons or their precursors being altered in $L I F R^{+/-}$mice. In any case, analysis of 
the function of TH-positive interneurons in periglomerular layer may further provide clues regarding the role or roles of adult forebrain neural stem cells. Although it is known that these periglomerular neurons receive innervation from olfactory receptor cells and regulate the activities of mitral and tufted cells (Shepherd, 1994), their actual function in olfactory behavior remains to be determined.

\section{REFERENCES}

Altman J (1966) Proliferation and migration of undifferentiated precursor cells in the rat during postnatal gliogenesis. Exp Neurol 16:263-278.

Alvarez-Buylla A, Temple S (1998) Stem cells in the developing and adult nervous system. J Neurobiol 36:105-109.

Artavanis-Tsakonas S, Rand MD, Lake RJ (1999) Notch signaling: cell fate control and signal integration in development. Science 284:770-776.

Barres BA, Burne JF, Holtman B, Thoenen H, Sendtner M, Raff MC (1996) Ciliary neurotrophic factor enhances the rate of oligodendrocyte generation. Mol Cell Neurosci 8:146-156.

Bartlett PF, Brooker GJ, Faux CH, Dutton R, Murphy M, Turnley A, Kilpatrick TJ (1998) Regulation of neural stem cell differentiation in the forebrain. Immunol Cell Biol 76:414-418.

Betarbet R, Zigova T, Bakay RA, Luskin MB (1996) Dopamine and GABAergic interneurons of the olfactory bulb are derived from the neonatal subventricular zone. Int J Dev Neurosci 14:921-930.

Bonni A, Yi S, Nadal-Vicens M, Bhatt A, Frank DA, Rozovsky I, Stahl N, Yancopoulos GD, Greenberg ME (1997) Regulation of gliogenesis in the central nervous system by the JAK-STAT signaling pathway. Science 278:477-483.

Burrows RC, Wancio D, Levitt P, Lillien L (1997) Response diversity and timing of progenitor cell maturation are regulated by developmental changes in EGF receptor expression in the cortex. Neuron 19:251-267.

Cameron HA, Hazel TG, McKay RD (1998) Regulation of neurogenesis by growth factors and neurotransmitters. J Neurobiol 36:287-306.

Chazal G, Durbec P, Jankovski A, Rougon G, Cremer H (2000) Consequences of neural cell adhesion molecule deficiency on cell migration in the rostral migratory stream of the mouse. J Neurosci 20:1446-1457.

Conover JC, Ip N Y, Poueymirou WT, Bates B, Goldfarb MP, DeChiara TM, Yancopoulos GD (1993) Ciliary neurotrophic factor maintains the pluripotentiality of embryonic stem cells. Development 119:559-565.

Craig CG, Tropepe V, Morshead CM, Reynolds BA, Weiss S, van der Kooy D (1996) In vivo growth factor expansion of endogenous subependymal neural precursor cell populations in the adult mouse brain. J Neurosci 16:2649-2658.

Cremer H, Lange R, Christoph A, Plomann M, Vopper G, Roes J, Brown R, Baldwin S, Kraemer P, Scheff S, Barthels D, Rajewsky K, Wille W (1994) Inactivation of the $N-C A M$ gene in mice results in size reduction of the olfactory bulb and deficits in spatial learning. Nature 367:455-459.

Dani C, Chambers I, Johnstone S, Robertson M, Ebrahimi B, Saito M, Taga T, Li M, Burdon T, Nichols J, Smith A (1998) Paracrine induction of stem cell renewal by LIF-deficient cells: a new ES cell regulatory pathway. Dev Biol 203:149-162.

Davis AA, Temple S (1994) A self-renewing multipotential stem cell in embryonic rat cerebral cortex. Nature 372:263-266.

DeChiara TM, Vejsada R, Poueymirou WT, Acheson A, Suri C, Conover JC, Friedman B, McClain J, Pan L, Stahl N, Ip N Y, Kato A, Yancopoulos GD (1995) Mice lacking the CNTF receptor unlike mouse lack CNTF exhibit profound motor neuron deficits at birth. Cell 83:313-322.

de la Pompa JL, Wakeham A, Correia KM, Samper E, Brown S, Aguilera RJ, Nakano T, Honjo T, Mak TW, Rossant J, Conlon RA (1997) Conservation of the Notch signalling pathway in mammalian neurogenesis. Development 124:1139-1148.

Doetsch F, Caille I, Lim DA, Garcia-Verdugo JM, Alvarez-Buylla A (1999) Subventricular zone astrocytes are neural stem cells in the adult mammalian brain. Cell 97:703-716.

Gadient RA, Lein P, Higgins D, Patterson PH (1998) Effect of leukemia inhibitory factor (LIF) on the morphology and survival of cultured hippocampal neurons and glial cells. Brain Res 798:140-146.

Gage FH (2000) Mammalian neural stem cells. Science 287:1433-1438.

Gaiano N, Nye JS, Fishell G (2000) Radial glial identity is promoted by Notch1 signaling in the murine forebrain. Neuron 26:395-404.

Galli R, Pagano SF, Gritti A, Vescovi AL (1999) Regulation of neuronal differentiation in human CNS stem cell progeny by leukemia inhibitory factor. Dev Neurosci 22:86-95.

Gard AL, Burrell MR, Pfeiffer SE, Rudge JS, Williams WC (1995) Astroglial control of oligodendrocyte survival is mediated by PDGF and leukemia inhibitory factor-like protein. Development 121:2187-2197.
Gheusi G, Cremer H, McLean H, Chazal G, Vincent JD, Lledo PM (2000) Importance of newly generated neurons in the adult olfactory bulb for odor discrimination. Proc Natl Acad Sci USA 97:1823-1828.

Heinrich PC, Behrmann I, Muller-Newen G, Schaper F, Graeve L (1998) Interleukin-6-type cytokine signalling through the gp130/Jak/STAT pathway. Biochem J 334:297-314.

Hughes SM, Lillien LE, Raff MC, Rohrer H, Sendtner M (1988) Ciliary neurotrophic factor induces type-2 astrocyte differentiation in culture. Nature 335:70-73.

Ip NY, Li YP, van de Stadt I, Panayotatos N, Alderson RF, Lindsay RM (1991) Ciliary neurotrophic factor enhances neuronal survival in embryonic rat hippocampal cultures. J Neurosci 11:3124-3134.

Ip NY, McClain J, Barrezueta NX, Aldrich TH, Pan L, Li Y, Wiegand SJ, Friedman B, Davis S, Yancopoulos GD (1993) The alpha component of the CNTF receptor is required for signaling and defines potential CNTF targets in the adult and during development. Neuron 10:89-102.

Johe KK, Hazel TG, Muller T, Dugich-Djordjevic MM, McKay RD (1996) Single factors direct the differentiation of stem cells from the fetal and the adult central nervous system. Genes Dev 10:3129-3140.

Kageyama R, Ohtsuka T (1999) The Notch-Hes pathway in mammalian neural development. Cell Res 9:179-188.

Koblar SA, Turnley AM, Classon BJ, Reid KL, Ware CB, Cheema SS, Murphy M, Bartlett PF (1998) Neural precursor differentiation into astrocytes requires signaling through the leukemia inhibitory factor receptor. Proc Natl Acad Sci USA 95:3178-3181.

Kornblum HI, Hussain R, Wiesen J, Miettinen P, Zurcher SD, Chow K Derynck R, Werb Z (1998) Abnormal astrocyte development and neuronal death in mice lacking the epidermal growth factor receptor. J Neurosci Res 53:697-717.

Kuhn HG, Winkler J, Kempermann G, Thal LJ, Gage FH (1997) Epidermal growth factor and fibroblast growth factor-2 have different effects on neural progenitors in the adult rat brain. J Neurosci 17:5820-5829.

Levison SW, Goldman JE (1993) Both oligodendrocytes and astrocytes develop from progenitors in the subventricular zone of postnatal rat forebrain. Neuron 10:201-212.

Levison SW, Chuang C, Abramson BJ, Goldman JE (1993) The migrational patterns and developmental fates of glial precursors in the rat subventricular zone are temporally regulated. Development 119:611-622.

Li M, Sendtner M, Smith A (1995) Essential function of LIF receptor in motor neurons. Nature 378:724-727.

Lillien L (1998a) Neural progenitors and stem cells: mechanisms of progenitor heterogeneity. Curr Opin Neurobiol 8:37-44.

Lillien L (1998b) Progenitor cells: what do they know and when do they know it? Curr Biol 8:R872-R874.

Lois C, Alvarez-Buylla A (1994) Long-distance neuronal migration in the adult mammalian brain. Science 264:1145-1148.

Marmur R, Kessler JA, Zhu G, Gokhan S, Mehler MF (1998) Differentiation of oligodendroglial progenitors derived from cortical multipotent cells requires extrinsic signals including activation of gp130/ LIFbeta receptors. J Neurosci 18:9800-9811.

Martens DJ, Tropepe V, van der Kooy D (2000) Separate proliferation kinetics of fibroblast growth factor-responsive and epidermal growth factor-responsive neural stem cells within the embryonic forebrain germinal zone. J Neurosci 20:1085-1095.

Martinou JC, Martinou I, Kato AC (1992) Cholinergic differentiation factor $(\mathrm{CDF} / \mathrm{LIF})$ promotes survival of isolated rat embryonic motoneurons in vitro. Neuron 8:737-744.

Marz P, Herget T, Lang E, Otten U, Rose-John S (1997) Activation of gp130 by IL-6/soluble IL-6 receptor induces neuronal differentiation. Eur J Neurosci 9:2765-2773.

Mayer M, Bhakko K, Noble M (1994) Ciliary neurotrophic factor and leukemia inhibitory factor promote the generation, maturation and survival of oligodendrocytes in vitro. Development 120:143-153.

Molne M, Studer L, Tabar V, Ting YT, Eiden MV, McKay RD (2000) Early cortical precursors do not undergo LIF-mediated astrocytic differentiation. J Neurosci Res 59:301-311.

Morshead CM, Reynolds BA, Craig CG, McBurney MW, Staines WA, Morassutti D, Weiss S, van der Kooy D (1994) Neural stem cells in the adult mammalian forebrain: a relatively quiescent subpopulation of subependymal cells. Neuron 13:1071-1082.

Morshead CM, Craig CG, van der Kooy D (1998) In vivo clonal analyses reveal the properties of endogenous neural stem cell proliferation in the adult mammalian forebrain. Development 125:2251-2261.

Murphy M, Dutton R, Koblar S, Cheema S, Bartlett P (1997) Cytokines which signal through the LIF receptor and their actions in the nervous system. Prog Neurobiol 52:355-378.

Nakamura Y, Sakakibara S, Miyata T, Ogawa M, Shimazaki T, Weiss S, Kageyama R, Okano H (2000) The bHLH gene hes1 as a repressor of the neuronal commitment of CNS stem cells. J Neurosci 20:283-293.

Nakashima K, Wiese S, Yanagisawa M, Arakawa H, Kimura N, Hisatsune T, Yoshida K, Kishimoto T, Sendtner M, Taga T (1999) Developmental requirement of gp130 signaling in neuronal survival and astrocyte differentiation. J Neurosci 19:5429-5434. 
Ohtani T, Ishihara K, Atsumi T, Nishida K, Kaneko Y, Miyata T, Itoh S, Narimatsu M, Maeda H, Fukada T, Itoh M, Okano H, Hibi M, Hirano $\mathrm{T}$ (2000) Dissection of signaling cascades through gp130 in vivo: reciprocal roles for STAT3- and SHP2-mediated signals in immune responses. Immunity 12:95-105.

Ohtsuka T, Ishibashi M, Gradwohl G, Nakanishi S, Guillemot F, Kageyama R (1999) Hes1 and Hes5 as Notch effectors in mammalian neuronal differentiation. EMBO J 18:2196-2207.

Oppenheim RW, Prevette D, Yin QW, Collin F, MacDonald J (1991) Control of embryonic motor neuron survival in vivo by ciliary neurotrophic factor. Science 251:1616-1618.

Pennica D, Shaw KJ, Swanson TA, Moore MW, Shelton DL, Zioncheck KA, Rosenthal A, Taga T, Paoni NF, Wood WI (1995) Cardiotrophin-1. Biological activities and binding to the leukemia inhibitory factor receptor/gp130 signaling complex. J Biol Chem 270:10915-10922.

Qian X, Shen Q, Goderie SK, He W, Capela A, Davis AA, Temple S (2000) Timing of CNS cell generation: a programmed sequence of neuron and glial cell production from isolated murine cortical stem cells. Neuron 28:69-80.

Rajan P, McKay RD (1998) Multiple routes to astrocytic differentiation in the CNS. J Neurosci 18:3620-3629.

Reynolds BA, Weiss S (1992) Generation of neurons and astrocytes from isolated cells of the adult mammalian central nervous system. Science 255:1707-1710.

Reynolds BA, Weiss S (1996) Clonal and population analyses demonstrate that an EGF-responsive mammalian embryonic CNS precursor is a stem cell. Dev Biol 175:1-13.

Reynolds BA, Tetzlaff W, Weiss S (1992) A multipotent EGFresponsive striatal embryonic progenitor cell produces neurons and astrocytes. J Neurosci 12:4565-4574.

Richards LJ, Kilpatrick TJ, Dutton R, Tan SS, Gearing DP, Bartlett PF, Murphy M (1996) Leukaemia inhibitory factor or related factors promote the differentiation of neuronal and astrocytic precursors within the developing murine spinal cord. Eur J Neurosci 8:291-299.

Rose TM, Weiford DM, Gunderson NL, Bruce AG (1994) Oncostatin $\mathrm{M}$ (OSM) inhibits the differentiation of pluripotent embryonic stem cells in vitro. Cytokine 6:48-54.

Seniuk-Tatton NA, Henderson JT, Roder JC (1995) Neurons express ciliary neurotrophic factor mRNA in the early postnatal and adult rat brain. J Neurosci Res 41:663-676.

Shepherd GM (1994) Discrimination of molecular signals by the olfactory receptor neuron. Neuron 13:771-790.

Sibilia M, Steinbach JP, Stingl L, Aguzzi A, Wagner EF (1998) A strainindependent postnatal neurodegeneration in mice lacking the EGF receptor. EMBO J 17:719-731.
Smith AG, Heath JK, Donaldson DD, Wong GG, Moreau J, Stahl M, Rogers D (1988) Inhibition of pluripotential embryonic stem cell differentiation by purified polypeptides. Nature 336:688-690.

Taga T, Kishimoto T (1997) Gp130 and the interleukin-6 family of cytokines. Annu Rev Immunol 15:797-819.

Tomasiewicz H, Ono K, Yee D, Thompson C, Goridis C, Rutishauser U, Magnuson T (1993) Genetic deletion of a neural cell adhesion molecule variant (N-CAM) produces distinct defects in the central nervous system. Neuron 11:1163-1174.

Tropepe V, Craig CG, Morshead CM, van der Kooy D (1997) Transforming growth factor-alpha null and senescent mice show decreased neural progenitor cell proliferation in the forebrain subependyma. J Neurosci 17:7850-7859.

Tropepe V, Sibilia M, Ciruna BG, Rossant J, Wagner EF, van der Kooy D (1999) Distinct neural stem cells proliferate in response to EGF and FGF in the developing mouse telencephalon. Dev Biol 208:166-188.

Turnley AM, Bartlett PF (2000) Cytokines that signal through the leukemia inhibitory factor receptor- $\beta$ complex in the nervous system. J Neurochem 74:889-899.

van der Kooy D, Weiss S (2000) Why stem cells? Science 287:1439-1441.

Wakamatsu Y, Maynard TM, Jones SU, Weston JA (1999) NUMB localizes in the basal cortex of mitotic avian neuroepithelial cells and modulates neuronal differentiation by binding to NOTCH-1. Neuron 23:71-81.

Ware CB, Horowitz MC, Renshow BR, Hunt JS, Liggit D, Koblar SA, Gliniak BC, McKenne HJ, Papayannopoulo T, Thoma B, Cheng L, Donovan PJ, Peschon JJ, Bartlett PE, Willis CR, Wright BD, Carpenter M (1995) Targeted disruption of the low affinity leukemia inhibitory factor receptor gene causes placental, skeletal, neural and metabolic defects and results in prenatal death. Development 121:1283-1299.

Williams RL, Hilton DJ, Pease S, Willson TA, Stewart CL, Gearing DP, Wagner EF, Metcalf D, Nicola NA, Gough NM (1988) Myeloid leukaemia inhibitory factor maintains the developmental potential of embryonic stem cells. Nature 336:684-687.

Yanagisawa M, Nakashima K, Taga T (1999) STAT3-mediated astrocyte differentiation from mouse fetal neuroepithelial cells by mouse oncostatin M. Neurosci Lett 269:169-172.

Yoshida K, Chambers I, Nichols J, Smith A, Saito M, Yasukawa K, Shoyab M, Taga T, Kishimoto T (1994) Maintenance of the pluripotential phenotype of embryonic stem cells through direct activation of gp130 signalling pathways. Mech Dev 45:163-171.

Young GM, Levison SW (1996) Persistence of multipotential progenitors in the juvenile rat subventricular zone. Dev Neurosci 18:255-265.

Zhu G, Mehler MF, Mabie PC, Kessler JA (2000) Developmental changes in neural progenitor cell lineage commitment do not depend on epidermal growth factor receptor signaling. J Neurosci Res 59:312-320. 